\title{
LINDANE AND PROPUXUR RESIDUES IN THE TOP SOILS OF SOME COCOA GROWING AREAS IN FIVE DISTRICTS OF THE CENTRAL REGION OF GHANA
}

\author{
J.K. Bentum, D.K. Essumang ${ }^{*}$ and D.K.Dodoo \\ Department of Chemistry University of Cape Coast, Cape Coast, Ghana
}

(Received July 28, 2005; revised January 28, 2006)

\begin{abstract}
Lindane and propoxur residues in some topsoil samples from five cocoa growing districts in the Central Region of Ghana have been determined. Ten soil samples were taken randomly at a depth of $0-10 \mathrm{~cm}$ from pre-selected farms in each district. Some physical and chemical properties of the soils were determined. The pesticide residues were extracted from $50 \mathrm{~g}$ of topsoil by continuous Soxhlet extraction using a $(1: 1 \mathrm{v} / \mathrm{v})$ acetone-chloroform mixture for six hours. Clean up of the extract was done by liquid-liquid partitioning and column chromatography using alumina and silica gel adsorbents. The pesticide residues were finally analysed by gaschromatography using ${ }^{63} \mathrm{Ni}$ electron capture detector (ECD) and flame ionization detector (FID) for lindane and propoxur, respectively. Lindane and propoxur pesticide residues were found to be present in all the soils to which these pesticides had already been applied. Generally, lindane residues occurred in greater amounts than propoxur. The concentrations of lindane ranged from 2.1 to $15.4 \mathrm{mg} \mathrm{kg}^{-1}$ and propoxur from 1.71 to $7.95 \mathrm{mg} \mathrm{kg}^{-1}$. Both the extracted lindane and propoxur residues correlated negatively with $\mathrm{pH}$, cation exchange capacity, moisture content, and organic carbon. Propoxur correlated positively with the amount of clay but there was no significant correlation between the amount of clay and the extracted lindane concentration.
\end{abstract}

KEY WORDS: Lindane, Propoxur, Soil, Pesticide monitoring

\section{INTRODUCTION}

The widespread use of pesticides and other noxious organic compounds in agriculture since the World War II has resulted in extensive environmental contamination. According to Rudd [1], the delayed expression of toxic symptoms amongst biological concentrators of these pesticides is a serious problem because it is insidious. It goes unnoticed until mortality results and even then the cause of mortality may be suspected. Although claims have been made on ill effects of these chemicals on human health, according to Kay [2] none of them has yet been conclusively confirmed. Gun and Stevens [3] and several workers have found that pesticides especially the organochlorines turn to remain on crops or penetrate into foodstuffs or accumulate in the soil. It is claimed that some food crops accumulate greater quantities of pesticide than the soil. Studies have also shown that pesticide residue levels are too low to detect in diet but are often concentrated in the adipose tissue of the human body and in breast milk of mothers [4-6].

Hassal [7] reported that propoxur (Unden or Baoyen) at $500 \mathrm{ppm}$ suppresses activity of some soil microorganisms for up to 16 days. In temperate regions, pesticide residues have been found in detectable amounts in soils after 50 years of application, but detection is limited to shorter periods in the tropics [8, 9]. Hill and other workers reported that the persistence of pesticides depends on such factors as, formulation in which the chemical is applied, the mode of application, the type of pesticide applied, the geographical location, temperature, moisture, soil organic matter, soil pH, clay content, the type of soil and microbial activity [10-12].

Some of these chemicals, despite the current ban and their restrictive use in the developed world, have found increasing use in developing countries. In Ghana, gamma BHC (Gamalin 20) 
and Unden 200, (a carbamate insecticide), are used extensively to control insect pest of cocoa [9].

The use of these pesticides on cocoa gave unusual flavour to cocoa preparation. In 1978 anonymous data submitted to the FAO - WHO indicated that the levels of lindane in cocoa beans from Ghana were between 0.0 and $0.3 \mathrm{mg} \mathrm{kg}^{-1}$ and in between $0.051-0.10 \mathrm{mg} \mathrm{kg}^{-1}$ in cocoa butter. The residue in cocoa mass was $0.038 \mathrm{mg} \mathrm{kg}^{-1}$. The FAO - WHO decided that the maximum residue limit should be $1.0 \mathrm{mg} \mathrm{kg}^{-1}$ [13]. Since these pesticides are systemic and can be translocated from the soil through the roots to other parts of the plant, it becomes necessary to investigate the levels of these pesticides in the soil. In the present work, lindane and propoxur residues in topsoil of ten tropical cocoa farms in five districts of the Central Region of Ghana have been determined and it was investigated whether the extracted pesticide residues correlated with the soil properties.

\section{Sample collection}

\section{EXPERIMENTAL}

Ten different samples of soils were collected from ten cocoa farms in five districts of the Central Region of Ghana. The soils were sampled at a depth of 0-10 cm, using a garden hand trowel. The samples were placed in appropriately labelled polythene bags, and stored in a refrigerator prior to analysis.

\section{Sample treatment}

The soil characteristics were determined using standard methods [14, 15] before the pesticides were extracted from them. $50 \mathrm{~g}$ sieved soil was weighed into a beaker and $10 \mathrm{~mL}$ of water sprinkled over it to increase its moisture content. The moist soil was transferred into a thimble and extracted with $200 \mathrm{~mL}$ of 1:1 acetone-chloroform mixture for six hours by the continuous Soxhlet extraction method. The extraction was repeated with another $50 \mathrm{~g}$ of soil and the two extracts were combined. The solvent was evaporated under reduced pressure using a vacuum evaporator and concentrated to $20 \mathrm{~mL}$. The residue was transferred to a separatory funnel and 20 $\mathrm{mL}$ of ethanoic acid-sodium ethanoate buffer solution added with shaking and then left to stand for one hour. The aqueous phase was separated from the organic phase. The organic layer was then divided into two equal portions. One half was used for lindane analysis and the other for propoxur.

For lindane, the extract was concentrated to $3 \mathrm{~mL}$ and then applied to a chromatographic column containing $20 \mathrm{~g}$ of activated alumina and eluted with $100 \mathrm{~mL}$ of hexane. The eluate was evaporated to $5 \mathrm{~mL}$ and transferred to another column containing $15 \mathrm{~g}$ of activated silica gel and eluted with $200 \mathrm{~mL}$ of $6 \%$ diethylether in petroleum ether at an elution rate of $5 \mathrm{~mL}$ per minute. The eluate was concentrated to $5 \mathrm{~mL}$, dried over anhydrous $\mathrm{Na}_{2} \mathrm{SO}_{4}$ and used for gas chromatographic determination using ECD.

The other half was concentrated to $3 \mathrm{~mL}$ and $10 \mathrm{~mL}$ of hexane added. This was extracted with $20 \mathrm{~mL}$ of acetonitrile and the hexane layer discarded. The acetonitrile layer was concentrated to $3 \mathrm{~mL}$ and transferred to a silica gel column containing $40 \mathrm{~g}$ of activated silica gel. The propoxur was then eluted with $150 \mathrm{~mL}$ of chloroform, at an elution rate of $5 \mathrm{~mL}$ per minute. The chloroform was evaporated, concentrated to $5 \mathrm{~mL}$ and dried over anhydrous $\mathrm{Na}_{2} \mathrm{SO}_{4}$. This aliquot was used for GC analysis using FID

The GC analysis of lindane was carried out using an HP 5890 Series II Gas chromatograph fitted with an on-column injector and ${ }^{63} \mathrm{Ni}$ ECD. The oven temperature was $200{ }^{\circ} \mathrm{C}$; injection point temperature was $200{ }^{\circ} \mathrm{C}$, capillary column (ID $0.53 \mathrm{~mm}$ film thickness, $1.5 \mu \mathrm{m}$ stationary phase DB-5; length $30 \mathrm{~m}$ ). $1.0 \mu \mathrm{L}$ of sample (extract) was injected into the column. Helium was 
used as a carrier gas $\left(1.0 \mathrm{~mL} \mathrm{~min}^{-1}\right)$, and Nitrogen as a make-up gas $\left(30 \mathrm{~mL} \mathrm{~min}^{-1}\right)$, the operating conditions were: detector temperature, $250{ }^{\circ} \mathrm{C}$; detector range $10^{-12} \mathrm{~A}(\mathrm{mV})^{-1}$.

Propoxur analysis was carried out using a Varian $3700 \mathrm{Gas}$ chromatograph fitted with an oncolumn injector and FID. The oven temperature was $300{ }^{\circ} \mathrm{C}$; injection point temperature, 310 ${ }^{\circ} \mathrm{C}$; capillary column (ID $0.53 \mathrm{~m}$ film thickness, $1.5 \mu \mathrm{m}$ stationary phase DB-5; length $30 \mathrm{~m}$ ). $0.5 \mu \mathrm{L}$ of sample (extract) was injected into the column. Helium was used as the carrier gas (30 $\left.\mathrm{mL} \min ^{-1}\right)$ and hydrogen as a make-up gas $\left(30 \mathrm{~mL} \mathrm{~min}^{-1}\right)$. The operating conditions were: detector temperature, $320{ }^{\circ} \mathrm{C}$ detector range $10^{-10} \mathrm{~A}(\mathrm{mV})^{-1}$.

Fourier Transformed infrared spectrophotometer (FIRT - 8201A) was used to analyze the extracted liquid samples, and that of the lindane and propoxur standards for the comparison of functional groups present in the extracts.

\section{RESULTS AND DISCUSSIONS}

The particle size distribution analysis of the soils revealed that the soils were characterized by high sand contents ranging between $73 \%$ and $86.5 \%$; low clay contents ranging from $3.94 \%$ to $7.7 \%$, and silt content ranging from $9.56 \%$ to $23.08 \%$ (Table 1). Soils from Juaso, $\mathrm{F}_{3}{ }^{2}$ (a village near Foso) and Twifo Mampong $\mathrm{TM}_{3}$, were loamy sand because of their high sand content and very low clay. The rest of the samples were sandy loam. The high sand contents of the soils are an indication of very low organic carbon or organic matter and the tendency of such soils to adsorb pesticides would be low [16]. This was observed for the soils with low organic carbon content ranging between $0.44 \%$ and $0.9 \%$. Hence these soils with very little organic matter would not retain much pesticide as observed. In addition persistence of pesticide in these soils would also be lower.

The soil moisture content ranges from $6.35 \%$ to $13.56 \%$. Low moisture content favours the adsorption of pesticides since the capacity of water molecules to displace pesticides and other organic compounds from adsorption sites, releasing the pesticide into the soil solution is reduced. The amount of pesticide adsorbed consequently, decreases with increasing moisture content [16].

Table 1. Soil characteristics.

\begin{tabular}{|l|l|l|l|c|r|}
\hline Soil samples & Sand \% & Clay $\%$ & Silt $\%$ & Texture & \multicolumn{1}{|c|}{ Moisture $\%$} \\
\hline Juaso $\underline{\mathrm{F}}_{3}$ & $81.08 \pm 0.39$ & $9.34 \pm 0.10$ & $9.56 \pm 0.17$ & SL & $6.66 \pm 0.01$ \\
Juaso $\underline{\mathrm{F}}_{3}$ & $83.13 \pm 0.36$ & $4.02 \pm 0.10$ & $12.85 \pm 0.11$ & LS & $6.35 \pm 0.01$ \\
Jukwa Jo & $74.04 \pm 0.33$ & $5.08 \pm 0.06$ & $20.88 \pm 0.10$ & SL & $12.66 \pm 0.05$ \\
Berase $\mathrm{B}_{24}$ & $73.03 \pm 0.17$ & $3.94 \pm 0.08$ & $23.08 \pm 0.10$ & LS & $10.97 \pm 0.07$ \\
Twifo Manpong $\mathrm{TM}_{3}$ & $86.45 \pm 0.07$ & $4.02 \pm 0.10$ & $9.35 \pm 0.08$ & SL & $8.01 \pm 0.20$ \\
Twifo Manpong $\mathrm{TM}_{6}$ & $81.09 \pm 0.25$ & $7.71 \pm 0.17$ & $11.20 \pm 0.10$ & SL & $9.33 \pm 0.14$ \\
Breman Asikuma BA & $79.75 \pm 0.22$ & $7.38 \pm 0.12$ & $12.87 \pm 0.21$ & SL & $8.29 \pm 0.12$ \\
Breman AsikumaBA & $72.75 \pm 0.12$ & $6.72 \pm 0.14$ & $20.53 \pm 0.14$ & SL & $10.66 \pm 0.14$ \\
Abura Dunkwa $\mathrm{AD}_{12}$ & $75.22 \pm 0.11$ & $6.35 \pm 0.13$ & $18.45 \pm 0.13$ & SL & $13.56 \pm 0.13$ \\
Abura Dunkwa $\mathrm{AD}_{8}$ & $74.10 \pm 0.15$ & $5.74 \pm 0.11$ & $20.16 \pm 0.11$ & SL & $12.50 \pm 0.09$ \\
\hline
\end{tabular}

The sand, clay and silt \% were measured on dry weight basis. SL - sandy loam, LS - loamy sand.

The $\mathrm{pH}$ of the soils ranges from slightly acidic $\mathrm{pH} 4.5$ to slightly neutral $\mathrm{pH}$ 7.48. Soils from Juaso, $\mathrm{F}_{3}{ }^{1}$ and $\mathrm{F}_{3}{ }^{2}$, and Jukwa Jo, are strongly acidic $(\mathrm{pH}<5)$ and soils from Abura Dunkwa $\mathrm{AD}_{8}$ and $\mathrm{AD}_{12}$ are slightly neutral. All the soils except $\mathrm{AD}_{8}$ (from Abura Dunkwa) have 
effective cation exchange capacity (ECEC) less than $10 \mathrm{cmol}_{\mathrm{c}} \mathrm{kg}^{-1}$, and are considered low activity clay. The soil from Abura Dunkwa, $\mathrm{AD}_{8}$, showed high ECEC. This could be attributed to its high ash content. The dried leaves on the farm are burnt occasionally; the ash produced contains $\mathrm{K}^{+}, \mathrm{Na}^{+}$and $\mathrm{Ca}^{+2}$, which cause an increase in the exchangeable base, a decrease in acidity, and a high $\mathrm{pH}$ which agrees with observations made by Oladokum and Nwoboshi [17, $18]$.

Table.2. Some chemical properties of the soils.

\begin{tabular}{|c|c|c|c|c|c|c|c|c|c|}
\hline \multirow{2}{*}{$\begin{array}{l}\text { Soil } \\
\text { sample }\end{array}$} & \multirow[t]{2}{*}{$\mathrm{PH}$} & \multirow[t]{2}{*}{$\%$ O.C. } & \multicolumn{6}{|c|}{ Exchangeable cations $\left(\mathrm{cmol}_{1} \mathrm{~kg}^{-1}\right)$} & \multirow{2}{*}{$\begin{array}{l}\text { ECEC } \\
\text { cmol }_{\text {kg- }}{ }^{1}\end{array}$} \\
\hline & & & $\mathrm{Ca}^{2+}$ & $\mathrm{Mg}^{2+}$ & $\mathrm{K}^{+}$ & $\mathrm{Na}^{+}$ & $\mathrm{Al}^{3+}$ & $\mathrm{H}^{+}$ & \\
\hline $\mathrm{F}_{3}$ & $4.50 \pm 0.14$ & $0.47 \pm 0.01$ & $0.70 \pm 0.01$ & $0.08 \pm 0.01$ & $0.36 \pm 0.01$ & $0.09 \pm 0.01$ & $0.12 \pm 0.02$ & $0.30 \pm 0.01$ & $2.37 \pm 0.10$ \\
\hline$\underline{\mathrm{F}_{3}}$ & $4.51 \pm 0.01$ & $0.62 \pm 0.02$ & $1.24 \pm 0.01$ & $0.08 \pm 0.01$ & $0.32 \pm 0.01$ & $0.07 \pm 0.01$ & $0.08 \pm 0.01$ & $0.30 \pm 0.01$ & $2.81 \pm 0.09$ \\
\hline Jo & $4.70 \pm 0.15$ & $1.02 \pm 0.01$ & $5.25 \pm 0.15$ & $1.00 \pm 0.01$ & $1.43 \pm 0.04$ & $0.06 \pm 0.01$ & $0.14 \pm 0.02$ & & $8.17 \pm 0.12$ \\
\hline$\underline{B}_{24}$ & $5.55 \pm 0.02$ & $0.64 \pm 0.15$ & $0.76 \pm 0.02$ & $1.20 \pm 0.07$ & $0.92 \pm 0.02$ & $0.08 \pm 0.01$ & $0.12 \pm 0.02$ & $0.28 \pm 0.02$ & $3.63 \pm 0.03$ \\
\hline $\mathrm{TM}_{3}$ & $5.64 \pm 0.05$ & $0.54 \pm 0.15$ & $1.53 \pm 0.04$ & $1.42 \pm 0.11$ & $0.42 \pm 0.02$ & $0.08 \pm 0.01$ & $0.12 \pm 0.01$ & $0.10 \pm 0.0$ & $3.67 \pm 0.10$ \\
\hline $\mathrm{TM}_{6}$ & $6.00 \pm 0.14$ & $0.62 \pm 0.01$ & $1.65 \pm 0.03$ & $1.40 \pm 0.10$ & $1.13 \pm 0.02$ & $0.10 \pm 0.01$ & $0.06 \pm 0.01$ & $0.10 \pm 0.03$ & $4.48 \pm 0.15$ \\
\hline $\mathrm{BA}_{1}$ & $6.06 \pm 0.04$ & $0.55 \pm 0.01$ & $2.56 \pm 0.08$ & $1.43 \pm 0.03$ & $0.35 \pm 0.01$ & $0.10 \pm 0.01$ & $0.10 \pm 0.01$ & $0.10 \pm 0.01$ & $4.64 \pm 0.17$ \\
\hline $\mathrm{BA}_{3}$ & $6.55 \pm 0.05$ & $0.60 \pm 0.02$ & $3.20 \pm 0.14$ & $1.60 \pm 0.15$ & $1.01 \pm 0.21$ & $0.09 \pm 0.01$ & $0.08 \pm 0.01$ & $0.14 \pm 0$ & $6.12 \pm 0.12$ \\
\hline $\mathrm{AD}_{12}$ & $6.59 \pm 0.07$ & $0.61 \pm 0.03$ & $4.50 \pm 0.14$ & $1.80 \pm 0.02$ & $0.60 \pm 0$. & & & & $7.22 \pm 0.14$ \\
\hline $\mathrm{AD}_{8}$ & $7.48 \pm 0.15$ & $0.82 \pm 0.02$ & $14.17 \pm 0.2$ & $2.80 \pm 0.04$ & $1.30 \pm 0.05$ & $0.30 \pm 0.03$ & $0.12 \pm 0.02$ & $0.04 \pm 0.01$ & $18.89 \pm 0.10$ \\
\hline
\end{tabular}

cmol $_{\mathrm{c}} \mathrm{kg}-{ }_{-}^{1}$ refers to centi mole charge per kilogram.

There were variations in the soil characteristics. The standard deviations of the soil characteristics determined (Table 3) revealed that the extent of variation follows the decreasing order of silt $>$ sand $>$ ECEC $>$ clay $>$ moisture $>\mathrm{pH}>$ organic carbon $>$ acidity. The persistence of lindane and propoxur in these soils would vary, and would therefore depend on the combined effects of all the soil characteristics on their degradation rate [19].

Table 3. Means and standard deviations of the soil characteristics.

\begin{tabular}{|l|l|l|}
\hline Soil characteristics & Mean & Standard deviation \\
\hline Silt & $14.86 \%$ & 5.30 \\
Sand & $78.06 \%$ & 4.83 \\
ECEC & $7.66 \mathrm{cmol}_{\mathrm{c}} \mathrm{kg}^{-1}$ & 3.64 \\
Clay & $6.76 \%$ & 3.19 \\
Moisture & $8.77 \%$ & 8.80 \\
pH & 5.76 & 0.98 \\
Organic matter & $0.65 \%$ & 0.16 \\
Acidity & 0.272 cmol $_{\mathrm{c}} \mathrm{kg}^{-1}$ & 0.11 \\
\hline
\end{tabular}

The mean concentrations of lindane and propoxur residues in the soils from the study gave 8.6 and $4.8 \mathrm{mg} \mathrm{kg}^{-1}$ of surface soil respectively. The level of lindane ranges from 2.1 to $15.4 \mathrm{mg}$ $\mathrm{kg}^{-1}$ whiles that of propoxur is from 1.71 to $7.95 \mathrm{mg} \mathrm{kg-}^{1}$ (Table 4). Generally, the levels of lindane were higher than the corresponding levels of propoxur in both the sandy loam and loamy sand soils. The standard deviation of lindane residues were 4.2 and that of propoxur was 2.1 indicating that the extent of variation in the levels of lindane residue is higher than that of propoxur. Lindane and propoxur residues were found in higher concentrations in soils collected from farms owned by the Ghana Cocobod, which are regularly and frequently sprayed with Gammalin 20 and Unden 200 pesticides; but the residues were lowest in soils which were not sprayed frequently with the pesticides. Correlation of soil properties with extractable lindane and propoxur were done to determine the factors responsible for the differences in the residue levels. (The level of significance was 0.05). 
Table 4. Mean concentration of pesticide residues in the soil analysed.

\begin{tabular}{|l|c|c|}
\hline \multirow{2}{*}{ Sample } & \multicolumn{2}{|c|}{ Pesticide residue $\left(\mathrm{mgkg}^{-1}\right)$} \\
\cline { 2 - 3 } & Lindane & Propoxur \\
\hline Juaso $_{3}{ }^{1}$ (near Foso) & 15.5 & 7.59 \\
Juaso $_{3}{ }^{2}$ (near Foso) & 9.98 & 7.95 \\
Jukwa Jo $_{\text {Brease }} \mathrm{B}_{24}$ & $<\mathrm{LOD}$ & $<\mathrm{LD}$ \\
Twifo Mampong $\mathrm{TM}_{3}$ & 13.1 & 1.71 \\
Twifo Mampong $\mathrm{TM}_{6}$ & 10.8 & 3.29 \\
Breman Asikuma $\mathrm{BA}_{3}{ }^{1}$ & 8.6 & 5.14 \\
Breman Asikuma $\mathrm{BA}_{3} 2$ & 7.1 & 4.2 \\
Abura Dunkwa $\mathrm{AD}_{12}$ & 5.6 & 5.5 \\
Abura Dunkwa $\mathrm{AD}_{8}$ & 4.7 & 5.93 \\
\hline
\end{tabular}

LOD of FID $=10^{-10} \mathrm{gL}^{-1}$. LOD of ECD $=10^{-12} \mathrm{gL}^{-1}$.

Hill et al. [10] and Mortland et al. [10, 23] observed an increasing rate of degradation with high moisture content; also high moisture content causes a decrease in pesticide concentration in the soil solution leading to desorption of pesticides from soil colloids. The desorbed pesticides are washed out of the topsoil by rain

Generally, the concentrations of both lindane and propoxur residues were higher in soils with the smaller amounts of organic carbon (or organic matter). Also the concentrations of both lindane and propoxur were higher in soils with lower cation exchange capacity (CEC). The levels of lindane were higher than the corresponding levels of propoxur in all the soils except soils from Abura Dunkwa, $\mathrm{AD}_{12}$. This means adsorption of pesticides differs with type of pesticide. Propoxur, which is slightly polar, is weakly absorbed since its adsorption is by hydrogen bonding. The weakly adsorbed pesticide may have been washed out of the topsoil by rain. Lindane, a non-polar molecule is probably adsorbed by organic matter and clay, either electrostacticaly or with some degree of chemical bonding (which is stronger than hydrogen bonding) and therefore could not be displaced easily from the active site by the action of water.

No significant correlation was found to exist between the amount of sand and the extractable lindane and propoxur residues. This could be due to the fact that the sand contents of the soils are high, between 70 and 90 percent. There was no significant correlation between the amount of clay in the soils and the extractable lindane. For example, the clay contents in $\mathrm{B}_{24}, \mathrm{TM}_{3}$ and $\mathrm{AD}_{12}$ correlated negatively with the lindane residues, while the clay contents in $\mathrm{F}_{12}, \mathrm{TM}_{6}$ and $\mathrm{AD}_{12}$ correlated positively with the lindane residue. This variation could be due to the kind of clay minerals present or the microbial activity in the soil. The correlation between the clay content and extractable propoxur residue was positive.

The specific frequencies of the IR spectra of both lindane and Propoxur residues were compared with that of their corresponding standards and each was found to be the same as that of the standards (Table 5A and 1B).

Table 5A. Specific IR frequencies of propoxur extract.

\begin{tabular}{|l|l|}
\hline Functional group & Specific frequencies $\left(\mathrm{cm}^{-1}\right)$ \\
\hline$-\mathrm{O}-($ ether$)$ & 1250 \\
\hline $\mathrm{C}=\mathrm{C}$ (benzene ring) & 1425 and 1450 (two peaks) \\
\hline $\mathrm{C}-\mathrm{N}-\mathrm{C}$ (secondary amide) & 1650 \\
\hline $\mathrm{C}=\mathrm{O}$ (ester) & 1700 \\
\hline $\mathrm{C}-\mathrm{H}$ & 2900 \\
\hline
\end{tabular}


Table 5B. Specific IR frequencies of lindane extract.

\begin{tabular}{|l|l|}
\hline Functional group & Specific frequencies $\left(\mathrm{cm}^{-1}\right)$ \\
\hline C-H & $2050(\mathrm{w})$ \\
\hline C-Cl & 1650 \\
\hline
\end{tabular}

\section{CONCLUSION}

In places where no pesticides had been applied, the tropical soils studied did not have any of the pesticide residues present at detectable levels. The concentrations of lindane and propoxur in the surface soils ranged from $2.1-15.4 \mathrm{mg} \mathrm{kg}^{-1}$ and $1.71-7.95 \mathrm{mg} \mathrm{kg}^{-1}$ of surface soil, respectively. Although there is no data on the safe maximum limits of lindane and propoxur residues in agricultural soils in the tropics, their presence in the soils reveal to some extent environmental contamination. These pesticides are systemic in nature, as observed by Antwi and Appoh [25, 26], particularly propoxur, and can be absorbed by the roots or leave of the cocoa plant and then translocated to other parts of the plant. It is therefore suspected that their accumulation over the years has led to an increase in the concentration of lindane and propoxur in the cocoa plant. In private cocoa farms where other crops are cultivated, the crops are likely to be contaminated by the application of these pesticides on the cocoa plantation.

The results of this research contribute significantly to the pesticide residue monitoring by the Ghana Environmental protection Agency, (Ghana EPA). It also constitutes a significant contribution to the joint FAO/WHO pesticide residue programe, which recommends strongly that individual countries should provide information on all relevant pesticide data to help the joint FAO/WHO meeting of experts on pesticides residue to make recommendations on the use of lindane and propoxur against cocoa pests.

\section{ACKNOWLEDGEMENTS}

We wish to thank all the farmers for their patience and support during the sampling process. Finally, we wish to thank the Government of Ghana for his financial support through the research and development fund.

\section{REFERENCES}

1. Rudd, L.R. Pesticide and the Living Landscape, University of Wisconsin Press: Wisconsin, U.S.A; 1970; pp 10-21, 140-148, 159-171, 220-238.

2. Kay, K. Environ. Res. 1977, 13, 74.

3. Gunn, D.L.; Stevens, J.G.R. (Eds.) Pesticide and the Human Welfare, 2nd ed., Oxford University Press: Oxford; 1978; pp 119-130, 220-238.

4. Haggard, S.B.; Brown, H.W.; Stull, J.W.; Whiting, F.M; Kembering, S.R. Bull. Environ. Contam. Toxicol. 1973; 9, 169.

5. WHO, Environmental Health Criteria 124-Lindane International Programme on Chemical Safety, Rome, 1991; Section 1.1.3 (IPCS).

6. Zweig, G.; Pye, E.L.; People, S.A. J. Agric. Food Chem. 1963, 11, 72.

7. Hassal, A.K. The Biochemistry and Uses of Pesticide - Structure, Metabolism, Mode of Action and Uses in Crop Protection, 2nd ed., Macmillan Press: Hong Kong; 1990; pp. 138, 172-195.

8. Nash, R.G.; Woolson, E.A. Science 1967, 157, 925. 
9. Perfect, T.J. Ambio. 1990, 9, 16.

10. Hill D.W.; McCarty, P.L. J. Water Pollut. Control. Fed. 1967, $29,1259$.

11. Iwata, Y.; Inestlake, W.E.; Gunthem, F.A. Arch. Environ. Contam. Toxicol. 1973, 1, 84.

12. Ohisa, N.; Kurihar, N.; Nakajima, M. Arch. Microbial. 1982, 131, 330.

13. FAO/WHO, Pesticide in Food, FAO/WHO report, 1978.

14. Kilmer, V.J.; Alexander L.T. Soil Sci. 1949, 68, 15.

15. David, R.L. Soil Science: Methods and Applications, John Willey and Sons: New York; 1994; pp 140-146.

16. Harris, C.I.; Warren, G.F. Weeds 1984, 12, 120.

17. Nwoboshi, C. Nigeria Agric. 1992, 9, 38.

18. Oladokum, M.A.O. Nigerian J. Agron. 1986, 3, 103.

19. Morill, C.B.; Mahilum C.; Mohiuddin S.H. Organic Compounds in Soil: Sorption, Degradation and Persistence, Arbor Science Publisher: Michigan, USA; 1982; pp 8-9, 159184, 246.

20. Nash, R.G.; Harris, W.G.; Lewis, C.C. J. Environ. Qual. 1973, 2, 290.

21. Parr, J.; Smith, S. Soil Sci. 1974, 18, 45.

22. Caro, J.H.; Freeman, H.D.; Clotfelty, D.E.; Tunner B.C.; Edwards W.M. J. Agric. Food Chem. 1973, 21, 1010.

23. Mortland, M.M.; Barake, N. 8th Int. Cong. Soil Sci.1974; pp. 433-443.

24. Allan Wild, Soil and the Environment, Cambridge University Press: Great Britain; 1996; pp. 257-259.

25. Antwi Boakye, F. Unpublished M. Phil Thesis, University of Ghana, Ghana, 1996; pp. 6670.

26. Appoh, F.E.; Dodoo, D.K.; Mantford, K.G. IAEA-SM, 1996, 343, 13. 